\title{
Ziya Gökalp'in Eğitim Felsefesi ve Yüksek Eğitim Hakkındaki Görüşleri
}

\author{
A.HADI ADANALI \\ YRD.DOC.DR, ANK ARA Ü. ILAHYYAT FAKÜLTESI \\ e-mail: adanali@divinity.ankara.edu.tr
}

\begin{abstract}
Ziya Gökalp's Philosophy of Education and his views on Higher Education. The article deals with Ziya Gökalp's views on higher education within the framework of his philosophy of education. Next, Gökalp's conception of humanities and social sciences is analyzed in the light of contemporary sociology of knowledge. Finally, Gökalp's views on higher education is evaluated in comparison with today's Turkish higher education. Gökalp's views reflect the positivist concept of sciences of his days and his distinction between culture an civilization leads to certain contradictions. Gökalp's philosophy of education, conservative and nationalistic in general, surprisingly contains some pragmatic and liberal aspects.
\end{abstract}

key words

Ziya Gökalp, Culture, Givilization, Philosophy of Education, Higher Education, Reform.

Son zamanlarda ülkemizde Yükseköğretim Kurulu Kanunu reformu hararetli bir şekilde tartışılmaktadır. Reformun gerekliliğini savunanlar, YÖK'ün üniversitelerinde bilimsel gelişmeler önünde bir engel teşkil ettiğini, siyasi hatta askeri müdahaleler için bir araç haline geldiğini savunmaktadır. Diğer yandan YÖK kanununda köklü bir reforma gerek duymayanlar, üniversitelerdeki bilimsel vasatlığı hukuki değil sosyokültürel ve ekonomik etkenlere dayandırmaktadır. Kabul edilen bir şey var ki, o da yüksek eğitim sistemimizin halihazırdaki durumunun pek iç açıcı olmadığıdır. Süregelen bu tartışmadan bir an geri çekilip ayn soruna, Türk düşünce tarihinin önde gelen isimlerinden biri olan Ziya Gökalp’in eğitim hakkındaki görüşleri açısından bakmak, yaklaşık yüzyla yakın bir süre içinde yüksek öğretimimizde hangi sorunlann çözüme kavuştuğunu ve hangilerinin kalıcı olduğunu belirlemek açısından yararlı olacaktır. Bu yazıda ilk olarak Ziya Gökalp'in eğitim felsefesini ele alacağız, daha sonra onun yüksek eğitim hakkındaki görüşlerini inceleyeceğiz. $\mathrm{Bu}$ incelememizde birinci elden kaynaklara, Gökalp'in kendi yazlanna önce- 
lik vereceğiz. Bir öğrenci, yazar ve eğitimci olarak Gökalp'in kişisel tecrübeleri göz önüne alındı̆gnda, onun eğitim hakkındaki görüşleri daha iyi anlaşlacağı için konuya geçmeden önce kısaca hayatından bahsetmek uygun olacaktir.

\section{Hayatı}

Gökalp 1876 ylinda Diyarbakur'da doğdu. Illkokuldan sonra, Askeri Rüşdiye (1886-1870) ve Mülkiye İdadî (1891-1894) mekteplerine devam etti. Bu arada, amcası Hasip Efendi'den Arapça, Farsça ve Islam felsefesi tedris etti ve hocası Rum doktor Yorgi'den Yunan felsefesi ve doğa bilimleri öğrendi. $O$ sıralarda Diyarbakar'da sürgünde olan Abdullah Cevdet ile tanıştı. Her ikisi sık sık bir araya gelip pek çok konuyu tartıştılar ve bu tartışmalar sayesinde Gökalp Avrupa'da dönemin moda entelektüel akumlanyla, özellikle de materyalist felsefe ve bazı sosyoloji ekolleriyle tanıştı. 1986 ylında İstanbul'a gitti ve Mülkiye Baytar Mektebine kaydoldu; fakat bu okuldaki resmi eğitimi, Itttihat ve Terakki Cemiyeti'yle bağlantul siyasi faaliyetleri sebebiyle bir yıl içinde sona erdi ve akabinde bir yl hapis cezası aldı. Cezasınun bitiminde, memleketi Diyarbakur'a sürgüne gönderildi. 1909'da İstanbul'u ziyaret etti ve İstanbul Üniversitesi'nde psikoloji ve sosyoloji alanunda kendisine yapulan hocalik teklifini maaşın düşük olması sebebiyle geri çevirdi. Aynı yl, İstanbul'dan Diyarbakır'a ilkokul müfettişi olarak atandı. ${ }^{1}$

1909 yllında İttihat ve Terakki Cemiyetinin toplantısına Diyarbakır delegesi olarak katılmak üzere Selanik'e gitti ve orada Cemiyetin ortaokulunda felsefe ve sosyoloji öğretmeni olarak görev aldı. ${ }^{2}$ Balkan savaşlannın akabinde, 1912'de İstanbul'a yerleşti ve 1915'de İstanbul Üniversitesi'nde (Darülfünun) açılan sosyoloji kürsüsüne ilk sosyoloji hocası olarak atand. ${ }^{3}$ Bu görevi 1919'da Askeri Mahkeme tarafından, Anadolu'daki Ermeni-karşıtlığına katılma suçlamasıyla Malta'ya sürgüne gönderilmesiyle sona erdi. Sürgün yllannda, "tek-kişilik bir üniversite" gibi, aralannda eski bakanlar ve meclis üyeleri bulunan pek çok arkadaşına dersler verdi. 1921'de Diyarbakır’a geri dö-

* Gökalp le ilgili bazı kaynaklara dikkatimi çeken Sayın Doç. Dr. Recai Doğan'a teşekkürlerimi iletirim.

Ziya Gökalp'in hayatı, eserieri ve gönüşleri hakkanda pek çok çalı̧̧ma yayınlanmışır. Bu çalışmalar ve özellikle hayatı ile ilgili yazılan eserler için blz. Zija Gökalp Biblijugrafjash, haz. Ismet Binark ve Nejat Sefercioğlu (Ankara: Türk Kültürü Araşurma Enstitüsü, 1971) s. 65.71. Aynca bkz. Hikmet Tanyu, Zija Gökalp Krondquisi (Ankara: Kültür Bakanliğ Yaynnlan, 1981); Taha Parla, The Social and Poditical Thought of Zija Gökalp 1887-1924 (Leiden: E. J. Brill, 1985); Uriel Heyd, The Famdations of Timkish Nationalism (London: The Harvill Press Ltd., 1950).

2 Heyd, Fandations, s. 32.

3 Parla, The Social and Pditical Thanght, s. 14. 
nüp ortaokulda ve Öğretmen Okulunda sosyoloji ve psikoloji dersleri vermeye başladı. ${ }^{4}$ Ölümünden bir müddet önce, Meclis Eğitim Komisyonu'nda görev aldı ve eğitim sistemi, müfredat ve ders kitaplan hakkında radikal reformlar teklif etti. 25 Ekim 1924'de İstanbul'da vefat etti. Eğitimle ilgili makaleleri başta Muallim (1916-1917) olmak üzere pek çok dergi, mecmua ve gazetede yaynnland1. ${ }^{5}$ Herhangi bir üniversiteden akademik bir derecesi olmamakla birlikte, eğitime olan ilgisi hayatı boyunca devam eden Gökalp sistematik bir eğitim teorisini dile getiren ilk Türk olarak kabul edilir. ${ }^{6}$

\section{Gökalp ve Ë̈itim Felsefesi}

Gökalp'in eğitim felsefesi onun kültür ve medeniyet arasında yaptığı ayınmı yansıtan iki önemli yön içermektedir. Terbiye ve talim.7 Ona göre terbiye toplumun, üyeleri üzerinde gerçekleştirdiği bir sosyalleştirme sürecidir. Bu sosyalleştirme sayesinde birey toplumun diline, edebiyatına, ahlakına, estetiğine ve mantığına aşina hale gelir. Bu açıdan terbiyenin amacı "milli bireyler" yetiştirmektir. Diğer yandan talim bireyin kozmik çevresine intibakıdır. Bu intibak kişinin doğal bilimlere kendini aşina kulması sonucu gerçekleşir. Talim sayesinde birey, maddi güçleri kullanabilir hale gelir.9 $\mathrm{Bu}$ ayınma ek olarak, Gökalp bilginin nesilden nesile aktanımında iki yaklaşımın olduğunu belirtir, bu yaklaşımlardan biri yaygın diğeri örgün eğitimdir. Illki doğal, kendiliğinden ve dinamiktir, diğeri ise, planl, sistematik ve durağandır. Yaygın eğitim toplumda mevcut ve yaşayan bilgileri sunar Diğer yandan, örgün eğitim, daha önceki nesillerin birikmiş zihinsel ürünlerini aktarır, temelde kitaplarda yazılı olanlan öğretir. Okul ve toplum her iki bilgiyi sunma yöntemini içermekle birlikte, terbiye eğitimle ilgili, talim ise öğretimle ilgili yöne öncelik verir.

Talim ve terbiye iki farklı hüküm alanına dayanmaktadır. Terbiye kaynağın toplumdan alan değer yargılanna dayanır ve değer yargılannın toplamına kültür denir. Değer yargılan görecelidir, milletten millete değişebilir. Terbiye

$4 \quad$ a.g.e., s. 16.

5 Gökalp’in eğitimle ilgili makaleleri günümüz diline kasmen sadeleştirilerek Ruza Kandaş tarafından basılmştur. Bkz. Ziya Gökalp, Makalder V, yay. haz. Ruza Kardaş (Ankara: Külrür bakanliğı Yayınlan, 1981) ve Ziyz Gökalp, Terbijerin Sxoual u Kültä̀d Temelleri I, yay. haz. Ruza Kardas (Istanbul: Milli Eğitim Bakanluğı Yayınlan, 1997). Gökalp'in eğitimle ilgili makalelerinin bir kasmı diğer makalelerle birlikte Niyazi Berkes tarafından İngilizce'ye tercüme edilmiş ve basılmıştır. Bkz. N. Berkes, Tuakish Nationalism and Westem Cinilization Selected Essons on Zija Gökalp (New York: Columbia University Press, 1959).

6 Andreas M. Kazamias, Education and The Quest for Modemity in Tuakey (Chicago: The University of Chicago Press, 1966), s. 108.

7 Gökalp, Terbijenin Sosyal ue Külä̈d Temalleri, s. 28.

8 a.g.e., s. 50 .

9 a.g.e., s. $172-173$. 
ile karşlaşturldağında talim, olgulara dayah hükümlenden oluşur. Bu yargılar bireyler ve toplumlar açısından değişmez. Gökalp terbiyenin milli veya kültürel, talimin ise uluslararası veya evrensel olması gerektiğine inanmaktadı. ${ }^{10}$

Gökalp'e göre Batı medeniyetinde son dönemde gerçekleşen önemli gelişmelerin temelinde iş bölümü yatar. $\mathrm{Bu}$ iş bölümünün neticesinde değişik bilim dalları ve uzmanlık alanlan ortaya çıkmıs, bu sayede bilimlerde üst düzey bir ilerleme kaydedilmiştir..11 Batı medeniyetiyle kyyaslandığında, Doğu medeniyeti bu iş bölümünü aynı düzeyde gerçekleştirememiştir. Doğu ve Batı arasındaki en temel fark da bu noktadadır. Bu yüzden Gökalp, Osmanlı İmparatorluğu'nu Batı emperyalizmi karşısında savunmanın tek yolunun, bilim, sanayi ve teknolojide Batlllara erişmek ve onlarla tamamen eşit düzeye ulaşmak olduğuna inanmaktadır. ${ }^{12}$

Gökalp daha önce gerçekleștirilen eğitim reformlanınn, mesela Tanzimat Islahatının, başanszzlığıı kültür ve medeniyet ve buna bağh olarak talim ve terbiye arasındaki ayınımı farknna vanlmamasına bağlar. Tanzimatçlar Doğunun ve Batınun talim ve terbiyesini birbirine kanş̧trdular. Neticede iki çeşit okul ortaya çıkt: geleneksel dini eğitim veren medreseler ve Avrupa tarzı eğitim veren mektepler. Gökalp'e göre, bu ikili durumun tek istisnası Avrupa tarzı eğitimi takip eden askeri okullardır (Harbiye ve Tibbiye). Gökalp bu okullarda Avrupalı meslektaslannnn dengi olan mükemmel uzmanlarnn yetiştiğini düşünmektedir. ${ }^{13}$ Gökalp askeri okullann milli (veya kïltürel) olan terbiye ile uluslararası (veya medeniyete dayali) talim arasındaki ayırmı desteklediğini düşünmektedir. Aynca ona göre bu ayırım, Batının bilim ve tekniğinin alııp Türk eğitimine başanyla uyarlanabileceğinin açık bir delilidir. Gökalp bu okullar eğitimde yapulacak reforma model olarak göstermektedir. $O$ şöyle sormaktadır.

Yeniçerinin savaş tekniği ile hekimbaşlann tp tekniği bu okullara girmiş olsaydı, bugünkü şanl kumandanlanmız ile şöhretli hekimlerimize sahip olabilecek miydik ${ }^{34}$

Bununla birlikte bu okullar eğitimde yaplması gereken reformun sadece bir kssmın teşkil eder gözükmektedir, çünkü bu okullar öncelikli olarak talime dayalidır. Başarlarnın sebebi Batıdan alunan bilgi ve tekniktir. $O$ halde

10 a.g.e., s. $27-28,48$.

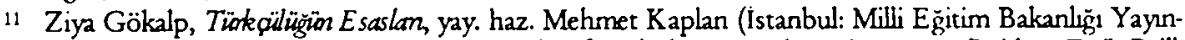
lan, 1999), s. 62; Ziya Gökalp, The Principles of Trokish, çev. Robert Devereux (Leiden: E. J. Brill, 1968), s. 45.

12 Gökalp, Tüakgilü̈̈̈̈n Esaslan, s. 64.

13 a.g.e., s. 65.

14 Gökalp, Terbijenin Sasyal re Kültünd Temelleri, s. 248. 
neden Gökalp bu okullan eğitimde reform için model olarak öne göstermektedir? Gökalp bu konuya değinmemekle birlikte, sanunm onun genel yaklaşımı dikkate alındığında, soru iki açıdan cevaplanabilir: İlk olarak bu okullar kendi sahalannda (askerlik ve tup) yetkin uzmanlar yetiştirmektedir. Bu alanlarda başarlidır ve bu başarılan örnek alınmalıdır. İkinci olarak, bu okullar sadece doktor ve askeri personeli eğitmekte, aynı zamanda Osmanl İmparatorluğunun sosyal ve siyasi sorunlanyla ilgilenen, çözümler arayan devlet adamlan yetiştirmektedir. Bu okullar eğitimde yapılması gereken reformun sadece talimle ilgili yönünü temsil etseler bile, onlann başansı "milli bireyler" yetiştirmede de model olarak alınabilir. Askeri okullar ve tup akademileri yaptuklan işte başanlı olsalar bile, bu başan sadece bilim ve teknolojinin Batıdan alınabileceği ve Türk eğitim sistemine uyarlanabileceğinin bir göstergesidir. Bu sebeple Gökalp'in bu okullan eğitim reformu için bir model olarak göstermesi, eğer onun talim ve terbiye arasındaki ayınm dikkate alınacaksa, eksik kalmaktadir.

\section{Gökalp'in Bilgi Sosyolojisi}

Gökalp’in eğitim hakkındaki görüşleri açısından bizi ilgilendiren diğer bir konu doğal bilimlerin Türk eğitim sistemi içinde meşnulaştırlmasıdır. Müslümanlann mantiğı, felsefeyi, fizik bilimlerini ve matematiği Bizansllardan aldıklanu belirten Gökalp, onlann dil biliminde ve estetik alanlanda yine Bizanslılann metotlann kullandıklanm ileri sürer. Benzer şekilde metafizik, ahlak ve politik bilimin kökleri Aristo'ya kadar uzanmaktadır. Orta Çăglar boyunca Doğuda ve Batıda skolastik düşünce hakimdi; fakat daha sonmalan, Batı skolastik düşünceyi terk etti ve her alanda büyük atulumlar gerçekleştirdi, yeni bilim dallan oluşturdu. Gökalp takip edilmesi gereken yolu şöyle belirtmektedir:

Aristo'nun istidlal mantığın bırakarak, Descartes ve Bacon'un istikra mantuğını ve bu mantıktan doğan metodolojiyi almanın dinimize ve milli kültürümüze ne zaran olabilir? Eski astronomi yerine yeni astronomiyi, eski fiziğe karşı yeni fiziği, eski kimyaya karşı yeni kimyayı almakla ne kaybederiz? Zoolojiye, botaniğe jeolojiye dair eski kitaplanmizda ne kadar bilgi bulabilmek imkanı var? Doğuda bulunamayan biyolojiyi, psikolojiyi, sosyolojiyi Batıdan almağa mecbur değil miyiz? Evvelce eski ilimlerimizin hepsini Bizans'tan almıştık Şimdi Rumlann ilimlerini Avrupa ilimleriyle değiştirsek, din ve kültür bakımından ne kaybederiz? ${ }^{15}$

Tabi tüm bu sorular hitabet amaçlıdır ve Gökalp doğal bilimlerin Batıdan alınmasında İslam dini ve Türk kültürü açısından hiçbir mahzur görme-

15 a.g.e., s. 47-48. 
mektedir. Gökalp'a göre doğal bilimler akal üzerine kurulu olup, müspet, tecrübeye dayalı ve değer yargılarından bağımsızdır, dolayısıyla herhangi bir değişikliğe uğratılmadan alınmalıdır.

Doğal bilimler hakkındaki bu görüse iki açıdan itiraz edilebilir. İlk olarak, günümüzde gerek felsefeciler gerekse bilim adamlan 19. yüzylın katı pozitivist anlayışına ihtiyatla yaklaşmaktadırlar. 20. yüzylda sadece doğal bilimler değil, matematik ve mantığın bile üzerine dayandığı temel aksiyomlann rasyonel olup olmadiğı sorgulanur hale geldi. Pozitivizme yöneltilen bu eleştiriler, çoğu bilim adamın teorilerine karşı göreceli veya pragmatik bir tutum taknmaya sevk etti. Mutlak bilgi felsefecilerin nihai hedefi olmaktan çıktı ve 'kesinliğin' yerini 'yüksek düzeyde muhtemel bilgi' aldı. Gökalp'in bilgi anlayışı bu gözden geçirilmiş epistemoloji ve ona yol açan gelişmeler karşssında güncel değerini yitirmiş görünmektedir. Aynca doğal bilimlerin kültürel arka plandan ne kadar bağımsız kalabileceği de sorgulanabilir. Bilimsel buluşlar değer yargılanna hiçbir atıfta bulunmadan sunulabilse de, bu doğal bilimlerin onlan ortaya çıkaran sosyal, kültürel ve psikolojik etkenlerden tamamen bağımsız hale getirilebileceği anlamına gelmez. Bu sebeple, temelde bilim ve kültür (veya değerler) bir iç içelik arz eder.

Gökalp'in bilgi anlayışına yöneltilebilecek illki ile bağlantıl ikinci itiraz, doğal bilimlerin kültür ve din üzerindeki etkileridir. Doğal bilimlerin gözlem ve tecrübeye, kültür ve dinin ise sosyal ve bireysel şuura dayandığın düşünmesi sebebiyle Gökalp, arada organik bir bağın olmadığın ilen sürmektedir. $\mathrm{Bu}$ ayınm bir an doğru olarak kabul etsek bile, bilimin dini olumsuz yönde etkilemeyeceğini düşünmek yanlış olur. Dinin ve bilimin bazı konularda farkh bakış açlanna sahip olması, ikisi arasında bir gerilime sebebiyet vermiştir. Maddeci bilim anlayışı İslamiyet için olduğu kadar Hıristiyanlık açısından da ciddi bir sorun oluşturur. Bazı bilimsel görüşlerin, mesela evrim teorisinin, dini açıdan ne tür zorluklara yol açtığı iyi bilinmektedir.

Sosyal bilimlere gelince, Gökalp bu bilimler hakkında doğal bilimlerde olduğu gibi bir genellemeye gitmemektedir. Ona göre sosyal bilimler, hem tecrübeye hem de değer yarglanna dayanmaktadır. Bu bilimlerin hem milli hem de evrensel yönleri vardır ve bu sebeple Batıdan neyin alınp neyin bırakulması gerektiği hususu hassasiyetle ele alınmalıdır. Gökalp milli ve evrensel yönlerinin olması sebebiyle bu bilimlerin toptan alınmasına veya toptan reddedilmesine karşı çıkmaktadır. Avrupa medeniyetinin gelenekleri ancak gümrük kontrolünden geçtikten sonra kültürümüze dahil olabilir. ${ }^{16}$

16 a.g.e., s. 44. 
Gökalp bu kontrol mekanizmasına ekonomi alanından bir örnek getirir. Uluslann Serzet'ni (The Wealth of Nations) yazdiğı dönemde Adam Smith, iktisadın evrensel ilkelerini bulduğuna inanyyordu. Aslinda, o sadece kendi döneminde İngiltere'nin milli ekonomisini anlatmıstt. İngiltere teknik açıdan yüksek bir düzeye ulaştı̆ı için, Smith teorisini serbest piyasa ekonomisi üzerine inşa etti. Fakat Amerika Birleşik Devletleri'nde Henry Carey ve Almanya'da Friedrich List serbest piyasa ekonomisinin kendi ülkeleri için uygulanabilir olmadığın gösterdiler. Onlar ekonomi teorilerini korumacı bir sistem üzerine olusturdular. Daha sonra Almanya kendi milli sanayïni kurduktan sonra, serbest piyasa ekonomisine geçmeye çalışt. Bu gözlemler ışı̆̆ında Gökalp şu hususu belirtmektedir:

O halde biz, milli sanayide ileri gitmiş milletlerin iktisat usullerini okullanmızda öğretimini yaptukşa yahut hayatumızda tatbik etrikçe, iktisatça yok olmaya doğru gidisimize hiç saşmamaliyzz. Bizim bu halimiz herhangi bir hastalikta faydası sabit olan bir ilacı bütün hastallklar için çare diye kullanmaya benzer. Her derdin çaresini bilen tabipler birçok fertleri öldürdükleri gibi, beşeri iktisat alimleri de birçok milletlerin yoksulluğuna sebep olmuşlardır. Bu milletlerden birisi de Türkiye olduğuna hiç şüphe yoktur. ${ }^{17}$

Sosyal bilimler için söz konusu olan bu husus beşeri bilimler için de geçerlidir, yani onlar da kültürel ve uluslararası (evrensel) öğelere sahiptir. Mesela felsefenin biri nesnel diğeri öznel iki yönü vardir. Felsefe bilime zıt olamaz, aynı zamanda bilimsel olgulan da çürütemez. Felsefe doğal bilimlerle uyum halinde olduğu sürece nesnel ve pozitif olacaktır. Felsefenin bu yönü uluslararasıder. Bilimin dışnda kalan alanlarda ise felsefe hürdür ve bu alanlarda ruhlara ümit ve mutluluk verir. Bu da felsefenin öznel yönünü olustrurur. "Buna göre felsefe, ilim gibi, milletlerarası olmağa mecbur değildir, millî de olabilir. Bundan dolaydır ki her milletin, kendisine göre bir felsefesi vardır. Yine bundan dolayidır ki ahlakta, estetikte, ekonomide olduğu gibi, felsefede de türkçülük olabilir." 18

Gökalp'in kültür ve medeniyet ayınmı pek çok açıdan eleştiriye uğramıştır. Bazı çağdaş yazarlar Gökalp'in bu ayınmınun temelinde sömürgecilik karşısında duyulan tepkinin yattı̆̆ıı düşünmektedir. Gerçekten de kültür ve medeniyet arasındaki aynmın, sömürgecilik alında gelisen milliyetçilik akumlannın tipik bir özellĭgi olduğu görülmektedir. Mesela benzer bir ayırıma Hint milliyetçiliğinde de rastlanur. ${ }^{19}$ Bununla birlikte Gökalp için bu açıklamanun geçerli olduğunu söyleyebilmek zordur. İlk olarak Gökalp Batı sömürgecili-

17 a.g.e., s. 175.

18 Gökalp, Tiakcoülügrion Esaslan, s. 185-86; Gökalp, The Principles of Tuakish, s. 127.

19 Bkz. Ahmet Bekmen "Türk Milliyetçilig̈i: Var Kalmanin Teyakkuz Hali," Modem Tiaktije'de Sijuasî Drüsünoe Millijețilik içinde, c. 4. yay. haz. Tanul Bora (istanbul: iletişim Yaynlan, 2002), s. 326. 
ğini sık sık eleştirse de, o kültür ve medeniyet arasındaki ayınımın araçsal değil bilimsel olduğuna inanmaktadır. Aynca bu ayrnma Alman düşüncesinde de rastlanur. Son olarak Gökalp bu konuda batıl yazarlardan E. Durkheim ve M. Mauss'tan esinlenmiştir. ${ }^{20}$

Uriel Heyd Gökalp'in kültür ve medeniyet ayırımından hareketle doğal ve sosyal bilimler arasındaki yaptığı kategorik ayırımı eleştirmektedir. Heyd'e göre, Gökalp sosyal bilimleri doğal bilimlere bağlayan güçlü bağların farkuna varamad. Ona göre, "genelde, doğa bilimleri ile toplum bilimleri ve özelde de Batının manevi kültürü ile Gökalp'in uygarlkk adını verdiği nesnel başarlann bağlayan güçliü bağlan ancak Gökalp gibi Avrupa'da hiç bulunmamış ve Avrupa kültürü üzerindeki bilgisi çok sınurl bir kimse görmemezlikten gelebilirdi."21 Heyd bu görüşünü Gökalp'in hayatından bir ömek ile destekler. Gökalp'in öğrencisi Enver Behnan Şapolyo Avrupa'ya tarih öğrenimi görmek üzere gitmek istediğinde Gökalp buna şiddetle karşı çıkar:

Onun görüşüne göre, (tamamen batıl kaynaklardan aldığı kendi alanı 'sosyoloji' de dahil olmak üzere) Avrupa'da beşeri bilimleri çalışmak bir hata olacaktı. Çünkü, (batılı hocalar) [Türk öğrenciyi] kendi milli kültürüne yabancı görüşlerin bir yorumcusu haline dönüştürecektir. Genç Türk doğal bilimleri ve teknik konulan batılı hocalarla çalışmalı ve modern bilimsel yöntemi onlardan öğrenmeli; tıpk Gökalp'in kendisinin Avrupa literatüründen öğrendiği gibi.22

Asıl mesele sosyal bilimlerin Avrupa'da çalışıp çalışılamayacağından ziyade, bu bilimlerin evrensel diyebileceğimiz bir yönteminin olup olmadığıdır. Gökalp'in yukanda Batı medeniyetinden almayı tavsiye ettiği Descartes ve Bacon'ın tümdengelimci yöntemleri amaca hizmet edemeyecek kadar genel ve soyuttur. Böyle genel bir yöntem olmasa da, her bir alan için kabul görmüs ve evrensel olarak tatbik edilen bir yöntem söz konusu mudur? Mesela, farklı felsefi ekollerin ortak referans kaynağı olan bir yöntemden bahsedilebilir mi? Felsefe açısından bu imkansız gözükmektedir, Bu yöntem Platon ve Hegel için diyalektik, Bergson için sezgi, Russell ve Moore için analiz, Heidegger ve Gadamer için hermenötiktir. Sanunm benzer durum Gökalp'in favori bilimi sosyoloji için de geçerlidir. Bu sebeple tek bir disiplin için bile birden fazla yöntemden bahsetmek daha uygundur. Farklı yöntemleri bir kenara bıraksak bile, Gökalp'in öğrencisine tavsiyesi diğer bir problemi içinde banndırmaktadır ki o da yöntemin içerikten nasıl aynlacağı sorunudur.

\footnotetext{
20 Hilmi Ziya Ülken, Tüakijede Cağdas Düşionce Taribi (İstanbul: Ülken Yaynnlan, 1988), s. 323, dipnot *.

21 Heyd, The Fandations, s. 81.

22 a.g.e., s. 81 .
} 
Pek çok düşünüre göre, yöntemi içeriğinden soyutlayp genel anlamda uygulayabilmek oldukç̧a zor hatta imkansızdır.

\section{Gökalp ve Yüksek Ë̆gitim}

Ziya Gökalp'in eğitim felsefesi ile ilgili görüşlerini belintikten sonra, onun yüksek eğitim hakkındaki düşüncelerine geçebiliriz. Kendinden önceki reformcular gibi, Gökalp eğitimde reformun üstten başlaması gerektiğine inanmaktaydı. "Milli maarif üniversiteden başlayarak, öğretmen okullanna ve sultanilere (lise) ve onlardan da ilkokullara inecektir." ${ }^{23} \mathrm{Bu}$ üstten aşağıya reform hareketi eğitimle ilgili uzun vadeli planlardan olduğu kadar acil ihtiyaçlardan da kaynaklanmaktaydı ve dönemin genel eğitim anlayışını yansıtmaktayd. Osmanl Imparatorluğu ordu ve sivil bürokrasi için iyi yetişmiş askerler, doktorlar, mühendisler ve yöneticilere şiddetle ihtiyaç duyuyordu. Yetişen nesilleri daha iyi eğitebilmek için, öğretmenlere gerek vardı; doğal olarak üniversite ve öğretmen yetiştiren okullar bu amaca hizmet edecek yegane yerlerdi. Başlangıçta medrese mezunlan mektepler için yeterli niteliğe sahip öğretmenler olarak düşünülse de, aşamalı bir şekilde öğretmen okullanndan mezun olan öğretmenler medrese mezunlannın yerini aldı. ${ }^{24}$ Gökalp'e göre, üniversite en önemli eğitim kurumudur. Mükemmel bir üniversite olmaksızın, orta dereceli okullarda ve ilkokulda ilerleme söz konusu olamaz.

Gökalp bilgiyi ikiye ayırmaktadır. Yaratıcı bilgi ve yaratılmış bilgi. Gökalp'e göre yaratıc bilgi “ilmin hakikatleri araştırurken kullandığ 1 faal usullerdir." 25 Diğer yandan, yaratılmıs bilgi, yaratıcı bilgi yoluyla keşfedilen bilginin tamamın oluşturmaktadır. Yaratulmıs bilgiyi diğer milletlerden almanın ve özümsemenin zor olması ve bilimsel konulardaki bağımsızlğı sınırlaması sebebiyle, öğrenciler yaratıcı bilgi kapasitelenini geliş̧tirmek üzere eğitilmelidirler. Gökalp yaratıcı bilgiye ezber karşısında büyük bir değer vermektedir. Gökalp yaratıcı bilginin Türk okullannda olmadığını düşünmekte ve ders kitaplann ezberlemeye yapılan aşı vurgu sebebiyle dönemindeki eğitim sistemini şiddetle eleştirmektedir. Gökalp kendi gramer öğretmeni tarafından kötü bir öğrenci olarak görülmüştü, çünkü o, Ahmet Cevdet Paşa'nın Karaid-i Osmanizye'sini ezberleyememiş ve bundan dolayı dersten düşük not almıştı. ${ }^{26}$ Gökalp'e göre yaratıcı bilgi, anlamaya öncelik verir. Aynca Gökalp bilimsel yaratıcllğın doğuştan olmadığın ve eğitim yoluyla kazanulabileceğini kabul

23 Gökalp, Terbijerin Soxyal re Kültründ Temelleri, s. 189.

24 "Maarif", Encodopetia of Islam Yeni Edisyon.

25

Gökalp, Terbiverin Socyal we Kültärol Temelleri s. 181.

26 a.g.e., s. 162. 
etmektedir. Üniversite yaratıcı bilginin olduğu (veya olması gerektiği) yerdir. Doğal olarak profesörler yeni bilimsel olgulan bulmak için çabalamalıdır. Gökalp Milli Eğitim Bakanı Şükrü Bey tarafından İstanbul Üniversitesine profesör olarak atandığı zaman, yaptı̆̆ konuşmada gerçek anlamda bilginin ne olduğunu bilen çok az kimsenin olduğundan yakunmıştı. Medrese mezunlan bilgiden sadece kelam ve fuksh gibi dini malumatı anlyyorlard. Diğer yandan Avrupa'da eğitim görmüş kimseler için bilgi Avrupalı alimlerin dediklerinden ibaretti. Ona göre gerçek alim bilimsel usulleri kalbinde canlı tutan ve araştırmalarıı ona göre yapan kimsedir. ${ }^{27}$

Gökalp'e göre, yaratıcluğ geliştiren bazı ön şartlar söz konusudur, bunlar arasında en önemlisi üniversitelerin özerkligidir. Siyaset ve kültür arasında bir denge kurulması gerektiğini savunan Gökalp, bu dengenin bozulduğunda her bir tarafın diğerine baskın çıkmaya çallşacağını öne sürer. Eğitim kültürün en duyarh alanlanndan biri olması sebebiyle siyaset tarafindan kolayca etkilenebilmektedir. Geçmişte hükümet niteliksiz insanlan eğitim kadrolanna atamaya başladığında, bir takım sözde alimler ortaya çıktı. Zamanla ilmî payeler ailevi konuma dayalı olarak beşikteki bebeklere kadar dağııldı. Bu trajediyi önlemenin tek yolu, üniversiteye özerklik kazandırmaktan geçmekteydi. Bu $\mathrm{da}$ ancak üniversitenin bilimsel meselelerde devletten bağımsız olması ve profesörlere tam olarak öğretim özgürlüğ̈̈ verilmesiyle mümkün olabilir. Gökalp İstanbul Üniversitesine atandığında, İttihat ve Terakki Cemiyetinin bazı üyeleri onun üniversitedeki diğer profesörleri Cemiyetin ideolojisine uygun olarak dersler verme konusunda etkileyeceğini ummaktaydı. Gökalp açıkça bunun söz konusu olamayacağını belirtti. ${ }^{28}$ Hükümetten akademik özgürlüğün teminatı almada ve bu özgürlüğ̈̈n İstanbul Üniversitesinde tesis edilmesinde Gökalp'in önemli bir rol oynadığı rahatlıkla söylenebilir. ${ }^{29}$

Eğitim Bakanlığnda iki çeşit kurula (idari ve bilimsel) ihtiyaç olduğunu söyleyen Gökalp, idari müdürlerden oluşan idari kurula yönetimle ilgili işleri, üniversite hocalanndan oluşacak yüksek eğitim kuruluna (medis-i kebir-i mearif) ise sadece eğitim öğretim işlerini burakur. Universitede profesörler oluşturulacak kurullarda hem yönetimi hem de eğitimi üstlenecektir. ${ }^{30}$ Bilimsel meseleleri idari işlerden ayrmada Gökalp'in iki temel hedefi vardır: (1) üniversite profesörlerini genel eğitimle ilgili konularda sorumlu tutarak üniversiteyi

27 Kazum, İsmail Gürkan, “Ziya Gökalp ve Üniversite," Zija Gäkalp Ị̇̆n Yazllandar ze Sölenerder içinde, yay. haz. Şevket Beysanoğlu, (Ankara: Asımlar Matbaası, 1978), c. iii, s. 151.

28 Gökalp, Terbijerin Sosyal ze Kültriond Temelleri, s. 188-89.

29 Gürkan, "Ziya Gökalp", s. 153.

so Gökalp, Terbijerain Sosyal ze Kültüpd Tenelleri, s. 188. 
genel eğitim sisteminin en üstüne yerleştirmek; (2) üniversite hocalann hem idari hem de eğitimle ilgili meselelerden sorumlu tutarak, üniversite öğretimini siyasetten ayırmak. Gökalp üniversite hocalanun siyasete kanş̧mamalan gerektiği yönündeki inancını geçmişte yaşanan tecrübelerle desteklemektedir. Geçmişte medrese hocalannun siyasete müdahale etmesi devlete karşı isyanlara sebep olmuştur. Üniversitedeki hocalı̆̆ esnasında, Gökalp siyasetten uzak kalma ilkesine sıkıca bağh kald. Üniversiteye atanmasindan sonra, Ittihat ve Terakki Cemiyetindeki görevini bıraktı ve siyasete kanşmadı; hatta üniversite yönetiminde herhangi bir idari görev dahi almadı. ${ }^{31}$ Gökalp devletin üniversiteler karşısında iki sorumluluğu olduğunu düşünür: mali destek vermek ve yeni bölümler açmak. Devletin mali desteği olmaksızın, üniversitesinin varlğını sürdürebilmesi imkansızdır. Peki yeni bölümlerin açılması neden profesörlerin değil de devletin sorumluğu dahilindedir? Bu Gökalp'in ilgilendiği bir soru değildir. Gökalp devletin müdahalesinin bu iki alana hasredilmesi gerektiği hususunda ısrarlıdır ve üniversitenin özerkliğini hususunda kaleme aldığı "Darülfünun" adlı şürinde siyasi otoriteye hitaben söyle seslenmektedir:

Bıraknuz bunlar kendi kendine,

Seçilsinler, siz seyirci kalınuz;

İlmi verin alimlere, siz yine,

Ele mülkün dizginin alınız.

Darülfünûn emirlerle düzelmez,

Onu yapar ancak serbest bir ilim;

Bir meleğe haricinden fer gelmez,

Biraknnz ilmi yapsin muallim!..32

Gökalp’e göre yaratıcllğı besleyen en önemli unsur özgür bir üniversite sistemidir. Üniversite öğretimi tamamen hür bir sistem üzerine dayalı olmalldır. Hocalar istedikleri konulan öğretmekte serbest olmah, öğrenciler de tercih ettikleri hocalann derslerini takip edebilmelidir. Özgürlük üniversiteye gerçek bir bilimsel atmosfer kazandıracak ve hocalara kendilerini akademik açıdan geliştirmeleri için motivasyon sağlayacaktır ve bu sayede hocalar arasında rekabet ortamı doğacaktur. Gökalp eğitimdeki rekabetin ticaretteki kadar faydalı olduğuna inanmaktadır. ${ }^{33}$ Gökalp başansız hocaların görevlerinden istifa etmeleri gerektiğini düşünür. Böylece bu görevlere gerçek alimler getirilecek ve devletin parası uygun bir şekilde harcanacaktır. Gökalp gerçek alimlerin cahillerden ayrıştırlmadığ ortamlarda bilimin gelişemeyeceğini

31 Gürkan “Ziya Gökalp,” s. 153.

32 Kazım Nami Duru, Zija Gökalp (İstanbul: Milli Eğitim Basımevi, 1975), s. 45.

33 Gökalp, Terbijenin Sosjal ue Kültäred Temelleri s. 186. Gökalp bu düşüncelerin baziların o dönemde Istanbul Üniversitesini ziyaret eden Alman akademisyenlerden almıştır. 
düşünmektedir. Bu oldukça liberal saylabilecek düşünceleri Gökalp'in yazllan arasında bulmak şaşırtıcı gelebilir, çünkü o sürekli olarak toplumu bireye tercih etmiştir. Gökalp'in eğitim felsefesinin temelinde bir çelişki mi vardır?

Gökalp'in temel amacı üniversiteyi gerçek alimlere sahip çıkan ve onlan diğerlerinden ayıran, liyakatin hakkının verildiği bir yer haline getirmekti. Medrese eğitim sisteminin yanlışlıklannın ve siyasi müdahalenin olumsuz etkilerinin farkına varan Gökalp, üniversitenin özerkliğini bilimin gelişmesi için bir ön şart olarak gördü. Üniversitenin özerkliği niteliksiz kimselerin üniversite hocalan arasına girmesine engel olsa da, hocaların atandıktan sonra akademik konumlannı geliştirmeleri için gerekli motivasyonu sağlayamayabilirdi. Gökalp önerdiği, rekabete dayalı eleyici sistemle, bu problemin çözülebileceğini düşünmüş̧ olmalıdır. Bireysel başan bu sistemin odak noktasın oluşturuyor gözükse de, Gökalp’i ilgilendiren asıl mesele milletin bilimsel hayatıydı. Başanlı bireyleri ödüllendirmekten ve başansızlan elemekten en büyük faydayı yine toplum görecektir; bu açıdan onun eğitim sisteminde bir çelişki olduğu söylenemez.

Aynca rekabete dayalı eleyici sistem Gökalp'in eğitim felsefesindeki ödüllendirme ve cezalandırmanın işlevleriyle uyumlu bir şekilde yorumlanabilir. Ödüllendirme ve cezalandırma aynı zamanda yaptırm (müeyyide) olarak da isimlendirilir. Yaptunmlann biri resmi diğer gayn resmi iki yönü vardır. Resmi yaptınmlar gerçek niteliklere karşlik geldiklerinde değer kazanurlar. Gökalp'a göre, daha önceki dönemlerde resmi ve gayn resmi yaptırumlar arasındaki fark oldukça büyüktü ve bu eğitimin gerilemesine sebep oldu. resmi ve gayn resmi ödüllendirme aradaki fark daha iyi gösterebilmek için Gökalp aşağıdaki ömeği vermektedir.

Vaktiyle İstanbul'da soylular sınıfı adıyla ilmî rütbesi olan ilimsiz alimler vardı. Halbuki, taşradan gelmiş birtakm hakiki allame resmi rütbelerden mahrumdu. Nadir Şah, dini bir anlaşma yapmak için İstanbul'a bir ilmi heyet göndermişti. Onlar, burada hakiki alimler varken, karşlanna sudur rütbesi verilmiş bir takum ulema-yı rüsumun çıktığını görünce ne yapacaklanın şaşırdılar. Buna göre, nezaketi elden bırakmayarak, "biz, memleketimizin usulü gereğince, ilmî rütbelenden mahrum bir heyetiz; buna göre, bizi rütbesi olmayan alimlerden meydana gelen bir heyetle görüstürürseniz, daha iyi olur" demeye mecbur olmuşlard..$^{34}$

Gökalp resmi ve gayn resmi ödüller ve cezalar arasındaki farkın tamamen ortadan kaldırlabilmesinin imkansız olduğunu düşünmektedir. Buna rağmen ceza ve ödüller adil bir şekilde uygulanmalıdır. Gerçek alimlere sahip

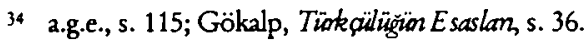


çımak ve diğerlerine yol vermek bu yaptınmlann uygun neticelerinden biri olacaktır. Gökalp’in öngördüğ̈̈ özgür üniversite, aynı zamanda öğrenciler açısından bazı pedagojik faydalar sağlayacaktır. Doğal olarak her bir öğrenci değişik konulara ilgi duyar. Seçme özgürlüğü sayesinde, öğrenciler psikolojik açıdan ilgi duymadıklan derslere devam etmeye zorlanmayacaklardır. ${ }^{35}$ Eğitimde motivasyonun önemi inkar edilemez. Motivasyonun kaynağını teşkil eden irade, ya coşkuya (vecde) ya da gayrete (cehde) dayanur. Öğrencilerin doğal eğilimlerini keşfetmek ve bu eğilimlerin gelişimini teşvik etmek, öğrenciyi motive etmenin en kolay yoludur. Ögrrenciliğinde Gökalp, arzu ettiği kitaplan okumaktan doğal bir zevk almış, zorlamay gerektiren derslerden hiç hoşlanmamıştır. $O$ kişiliğinin bu yönünün hayats boyunca devam ettiğini itiraf etmektedir. ${ }^{36}$ Bununla birlikte Gökalp eğitimde gayretin önemini de inkar etmez.

Gökalp’in bazı yönleriyle liberal saylabilecek yüksek eğitim sistemi, tüm öğrenciler için ortak bir müfredat takip etmeyen Amerikan üniversitelerini çağrıştursa da arada temel bazı farklar vardır. Illk olarak, Gökalp üniversite eğitiminde uzmanlaşmaya özgürlük kadar önem vermektedir ve üniversite uzmanlık eğitiminin alındığı yerdir. Bu süreci kolaylaştırmak için, Gökalp liselerin fen bölümlerinden mezun olan öğrencilere ilgili alanlarda üniversite eğitim almalanm (tıp, mühendislik vs) salik vermekteydi. Edebiyat bölümünden mezun olan öğrencilere ise hukuk ve beşeri bilimleri okumasın tavsiye ediyordu. İkinci olarak, Gökalp doğal bilimleri okuyacak öğrencilere felsefe dersini, beşeri bilimleri okuyacak öğrencilere de hem felsefe hem sosyoloji derslerini zonunlu görüyordu. Gökalp'in belli bir dalda özgürlüğü vurgulayan dengeli bir sistemi öngördüğ̈nü söylemek daha doğru olur. ${ }^{37}$

\section{Sonuç}

Amerikalı felsefeci John Dewey'e göre eğitim hayata bir hazırlık olmayıp, hayatla iç içe bir süreçtir. Dewey gibi Gökalp de tüm hayatın bir eğitim süreci olduğuna inanur. Yine Dewey gibi Gökalp, eğitimin kozmik ve kültürel çevreye uyum sağlamanın bir aracı olduğunu düşünür. Gökalp hiçbir zaman eğitimle ilgisini kesmedi; sınfta verdiği derslerini ders dışında etrafında oluşan gruplara yaptığı konuşmalar takip etti. Malta'da sürgünde iken bile arka-

35 Gökalp Terbijerion Sosyal re Küllörd Temelleri, s. 187.

36 a.g.e., s. 163.

37 Hikmet Yildınm Celkan'in Gökalp'i “öğrencilerin istediği okula girip okuması"n ileri sürüyor şeklinde yonumlaması tam olarak doğru değildir, bkz. Hikmet Yuldınm Celkan, Zija Gökalp'in Ë̈tiom Sos. yolg̈̈si (Istanbul: Milli Eğitim Bakanly̆ğ Yayınlan, 1990), s. 135. 
daşlanna ders vermeye devam etti ve gönderdiği mektuplarla kızlarının eğitimine katkada bulunmaya çalıştı. Gökalp'in tüm gayretleri bilgi ile hayat arasunda bir köprü kurmaya yönelikti. Bu açıdan onun eğitim felsefesinin pragmatik bir yönünün olduğu söylenebilir. Diğer yandan yüksek öğretimde özgürlüğe verdiği önem ve öngördüğü rekabete dayalı sistem onun eğitim felsefesindeki liberal yönü temsil eder. Diğer konulardaki görüşlerinde olduğu gibi Gökalp eğitimde, olguyla değer, teoriyle pratik ve sorumlulukla özgürlük arasında bir denge aramaya çalışmıştır. Bu sebeple onun eğitim felsefesi sentetik bir yap1 arz eder. Gökalp Türk eğitim sisteminin problemlerini teşhiste oldukça başanlıydı. Bu problemlerin çoğu ve özelliklede yüksek öğretimle ilgili olanlan günümüzde hala varlıklann devam ettirmektedirler.

Üniversitelerimizin özerk olduğunu ve eğitimin hür bir atmosferde gerçekleştiğini söyleyebilmek mümkün değldir. Her ne kadar rektör, dekan ve bölüm başkanları seçimle belirleniyor gözükse de, merkezi ve siyasi otoritenin tercihi ve onay gerekmektedir. Üniversite eğitim sistemimizin genel felsefesi Gökalp'in önemle üzerinde durduğu dini, milli ve kültürel değerlerimizle ne derece uyum içinde olduğu tartışlabilir. Eğitim dilinden başörtüsü yasağına kadar pek çok konuda kendi değerlerimizle çatışan uygulamalar, uyulması zorunlu "medeni ve çağdaş" değerler olarak görülmektedir. Üniversitelerimizde eğitim "yaratıc" ve eleştirel olmaktan çok ezbere dayalıdır. Maalesef mevcut sinav sistemi bu ezberciliği pekiştirmektedir. Özellikle teknik alanlarda eğitim gören öğrencilerin, sosyal ve beşeri bilimlerden nasibi Türkçe ve Inkılap tarihi dersleriyle sınurlıdır. Aradan yaklaşık yüz yl geçmesine rağmen Gökalp'in görüşleri bu sorunlan aşmamızda bizlere hala ışık tutabilir. 